\title{
Pewarisan Seni Wayang Golek Di Jawa Barat
}

\author{
Soni Sadono ${ }^{1}$, Catur Nugroho ${ }^{2}$, Kharisma Nasionalita ${ }^{3}$ \\ 1Prodi Seni Rupa FIK Telkom University, ${ }^{2}$ Prodi Ilmu Komunikasi FKB Telkom \\ University, ${ }^{3}$ Prodi Ilmu Komunikasi FKB Telkom University
}

\begin{abstract}
As the improvement of increasingly sophisticated technology and the variety of modern communication media, such as television, radio, magazines, and the internet, the communities experienced a change of communication and entertainment media. So diverse regional arts and culture in Indonesia provides opportunities for various parties to be able to pass on to the younger generation and use it as a medium of communication. One of the local cultural arts passed down from generation to generation of is Golek Puppets (Wayang Golek). Golek puppet indeed been utilized by leaders and government in conveying information, knowledge and teachings to the society. Dissemination of information that is still centered on the urban areas, led to information gap between the people who live in urban areas with the people who live in the countryside. Meanwhile, the condition of people in West Java is still largely residing in rural areas. This is one of the reasons why this medium of Golek Puppet folk art is still used in guarding cultural and values heritage, also as dissemination of information media. This research is related to guarding of cultural heritage and development communication strategy. The theory used in this paper is Heriter La Culture Theory which describes the concept of cultural inheritance. While the method used is the method of phenomenology, where research focused on phenomena or events that are unique and special. In this research, the use of wayang golek art as a communication medium is something unique because while technology is more modern, some parties in West Java still maintain the traditional communication media that is, the art of wayang golek show. In the development of Golek Puppet in West Java, almost all stakeholders involved using the conservation, reinterpretation, and revitalization system.
\end{abstract}

Keywords : Cultural inheritance, Golek Puppet, Phenomenology, Heritere La Culture Theory

\section{PENDAHULUAN}

Perkembangan dan kemajuan teknologi serta kehadiran internet beberapa tahun terakhir membuat masyarakat mulai mempertanyakan pembangunan dari pemerintah serta menyuarakan perubahan. Seperti yang dikatakan Dilla
(2010:99) bahwa munculnya kesadaran masyarakat terhadap permasalahan seputar keterbelakangan, kemiskinan, dan kesejahteraan. Menyadari pentingnya tuntutan perubahan membuat paradigma pembangunan mulai bergeser dari hanya bertumpu pada ekonomi dan infrastruktur menjadi ke arah pembangunan yang harus 
mewakili potensi manusia dan konteks sosialnya. Selantunya perkembangan dan perubahan dengan memanfaatkan teknologi informasi dan komunikasi.

Kehadiran teknologi serta internet memang telah memberikan perubahan dalam kehidupan masyarakat kearah yang lebih baik serta kemudahan kepada masyarakat dalam memperoleh informasi, namun dilain sisi intenet juga dapat memberikan dampat yang buruk bagi kehidupan masyarakat. Salah satu akibatnya adalah terjadinya peningkatan kenakalan remaja, seperti pornografi. Apalagi, Indonesia termasuk dalam negara dengan penggunaan internet terbanyak ke-6 di dunia. Seperti yang dikutip dari website kominfo.go.id bahwa Kementerian Komunikasi dan Informatika

(Kemenkominfo) menyatakan, pengguna internet di Indonesia sampai tahun 2017 telah mencapai 112 juta orang. Dengan capaian tersebut, Indonesia berada pada peringkat ke-6 di dunia. Dari jumlah pengguna internet tersebut, 80 persen di antaranya adalah remaja berusia 15-19 tahun. Melihat semakin berkembang dan beragamnya media baru saat ini, dengan berbagai macam varian dan fitur yang dimiliki menjadikan media baru (internet) sebagai media yang banyak digunakan oleh sebagian besar masyarakat.

Disaat perkembangan teknologi yang semakin canggih serta beragamnya media komunikasi modern, seperti internet, beberapa pihak masih mempertahankan kesenian rakyat wayang golek sebagai media komunikas. Dinas Komunikasi dan Informatika (Diskominfo) Jawa Barat dari tahun 2015 melaksanakan program sosialisasi dan diseminasi informasi ke beberapa sekolah di Jawa Barat untuk mengkampanyekan gerakan internet sehat dan gerakan anti narkoba. Beberapa tokoh budaya di Jawa Barat juga masih berusaha mempertahankan kesenian wayang golek sebagai warisan budaya dan media penyampai informasi.

Namun, jika melihat kembali lebih jauh sebelum kehadiran media komunikasi modern seperti televisi, radio, majalah, maupun internet. Kesenian rakyat memang telah dimanfaatkan oleh para pemimpin dan pemerintah dalam menyampaikan informasi, pengetahuan serta ajaran kepada masyarakat. Dengan 700 lebih suku di Indonesia, terdapat ratusan bahkan ribuan kesenian daerah yang sudah sepatutnya diwariskan dan digunakan sebagai media komunikasi dan sosialisasi di masyarakat.

Penyebaran informasi yang masih berpusat diperkotaan melatarbelakngi terjadinya kesenjangan informasi antara masyarakat yang tinggal diperkotaan dengan masyarakat yang tinggal dipedesaan. Sedangkan, kondisi masyarakat di Jawa Barat sebagian besar masih bertempat tinggal di wilayah pedesaan. Karena penggunaan media komunikasi modern belum mampu menjangkau semua lapisan masyarakat terutama masyarakat yang bertempat tinggal di pedesaan. Maka banyak pihak menggunakan kesenian rakyat sebagai media komunikasi sosial dan pembangunan.

Seperti yang diketahui bahwa wayang golek merupakan salah satu seni pertunjukan rakyat yang berasal dari wilayah Pasundan (Provinsi Jawa Barat).. Penamaan wayang golek karena wayangnya terbuat dari bahan kayu yang menyerupai bentuk manusia. Boneka yang terbuat dari kayu tersebutlah yang disebut dengan golek sehingga diberi 
nama wayang golek. Dalam kehidupan masyarakat di Jawa Barat kesenian wayang golek difungsikan kedalam dua bentuk pergelaran, yaitu sebagai media hiburan dan sebagai upacara ritual.

Komunikasi yang terjadi pada pertunjukan wayang golek adalah komunikasi tatap muka secara langsung antara dalang sebagai pelaku seni dengan penonton. Oleh karena itu, seni pertunjukan rakyat wayang golek dipergunakan sebagai media komunikasi untuk penyampaian informasi dan pesan-pesan tertentu, sebagaimana pemanfaatan media modern yang berfungsi untuk mentransmisikan pesan, menghibur, mendidik, dan mempengaruhi (mempersuasi) khalayak atau masyarakat. Pesan-pesan yang dikomunikasikan dalam pertunjukan wayang golek dapat ditransimisikan melalui simbol-simbol yang berupa bahasa (verbal) dan simbol non verbal seperti warna, kostum, musik dan gerakan tokoh wayang yang memiliki makna masing-masing.

Peran seni pertunjukan rakyat sebagai media komunikasi dan penyebaran informasi tentang pembangunan memang masih relevan digunakan untuk saat ini. Seni pertunjukan rakyat masih relevan digunakan sebagai media penyebaran informasi karena dalam menyampaikan pesan, kesenian rakyat penuh dengan kesederhanaan dengan pengunaan bahasa sehari-hari (merakyat), juga lebih komunikatif sehingga mudah dimengerti oleh penonton. Penyampaian pesan yang dikemas dalam bentuk guyonan yang disampaikan oleh dalang cenderung lebih menyentuh dan lebih dapat diterima dibandingkan melalui media lain yang menonjolkan sikap emosional, atraktif dan konfrontatif. Selain itu, dengan penyampaian pesan melalui kesenian rakyat, sekaligus sebagai media pengenalan dan pewarisan budaya kepada generasi muda.

Penyampaian pesan sosial dan pembangunan kepada masyarakat tidak akan terlepas dari kebudayaan masyarakat itu sendiri. Sehingga penggunaan wayang golek sebagai media penyebaran berbagai macam informasi masih relevan dan efektif untuk digunakan sebagai media komunikasi atau pembawa pesan pembangunan. Penggunaan wayang golek sebagai media penyebaran informasi di tengah perkembangan teknologi yang semakin modern menjadikan fenomena ini menjadi unik dan menarik untuk ditelusuri lebih mendalam. Penelitian ini terkait dengan strategi komunikasi pembangunan dan penjagaan terhadap warisan budaya. Teori "Heriter La Culture" yang menjelaskan tentang konsep pewarisan budaya. Sedangkan metode yang digunakan adalah metode fenomenologi, dimana penelitian difokuskh fenomena atau kejadian yang unik dan bersifat khusus. Pada penelitian ini penggunaan kesenian rakyat wayang golek sebagai media komunikasi merupakan sesuatu yang unik karena disaat teknologi semakin modern, Diskominfo Jawa Barat masih mempertahankan media komunikasi tradisional yaitu, seni pertunjukan wayang golek.

Dari uraian latar belakang di atas, peneliti melihat sejumlah gejala yang menunjukkan urgensi penelitian atas fenomena budaya, yakni perpaduan hadirnya teknologi komunikasi yang belum sepenuhnya dapat menjadi jawaban bagi diseminasi informasi dan pewarisan budaya. Identifikasi tersebut sebagaimana tertuang dalam beberapa poin yaitu adanya keterlibatan publik 
secara langsung dalam proses diseminasi informasi dan pewarisan budaya, dalam hal ini adalah penggunaan kesenian rakyat wayang golek. Selain itu juga adanya penyelenggaraan komunikasi aktif antara pemangku kepentingan (goverment) dengan warga negara melalui media komunikasi tradisional. Berdasar latar belakang dan identifikasi masalah penelitian, maka dapat dirumuskan masalah penelitian yang menjadi fokus kajian dalam penelitian ini yaitu bagaimana strategi pewarisan budaya kesenian wayang golek yang dilakukan oleh berbagai pihak di wilayah provinsi Jawa Barat dan bagaimana pemanfaatan kesenian wayang golek sebagai salah satu media komunikasi sosial di wilayah Provinsi Jawa Barat.

Penelitian ini diharapkan dapat memberikan konstribusi dalam rangka pengembangan ilmu pengetahuan dalam kajian ilmu komunikasi khususnya bidang media komunikasi tradisional dan komunikasi pembangunan serta pewarisan budaya. Selain itu penelitian ini diharapkan bisa menjadi bahan rujukan bagi daerah lain yang ingin mengembangkan strategi komunikasi sosial dan pembangunan dan pewarisan kesenian rakyat kepada generasi muda.

Media tradisional atau media rakyat merupakan bentuk media lokal dalam suatu komunitas budaya. Keberadaan media ini sudah lama dimanfaatkan oleh komunitas budaya untuk menjalin interkasi dan komunikasi diantara komunitas tersebut sebelum kehadiran media massa modern. Dissanayake dalam Dilla (2010 : 136) mendefinisikan media komunikasi tradisional sebagai suatu sistem komunikasi yang melekat dalam kebudayaan yang telah eksis sebelum media massa muncul, dan masih eksis sebagai mode komunikasi. Media rakyat atau media komunikasi tradisional terdiri dari teater rakyat, pewayangan, penceritaan atau kisah-kisah, tarian rakyat, balada, dan lawakan (Dilla : 2010)

Dananjaya (1986) mengatakan bentukbentuk media komunikasi tradisional yang ada dan hidup dalam tradisi seni masyarakat lokal Indonesia adalah folklore, cerita prosa rakyat (mitos, legenda, dongeng), ungkapan rakyat (peribahasa, pepatah, pemeo,dan lainlain), puisi rakyat, nyanyian rakyat, teater rakyat dan alat-alat bunyi-bunyian. Media komunikasi tradisional adalah adaptasi media untuk digunakan oleh masyarakat yang bersangkutan, apapun tujuannya ditetapkan oleh masyarakat itu. Media ini adalah media yang memeberi kesempatan kepada warga masyarakat sebagai perencana, pemroduksi sekaligus pelaksana.

Jadi, media rakyat atau tradisional merupakan media yang dikembangkan dan dikelola oleh orang-orang yang memiliki nilai-nilai dan cita-cita atau kehendak yang sama disebuah wilayah yangs segi geografisnya terbatas. Adapun yang termasuk kedalam media komunikasi tradisional adalah seni pertunjukan rakyat. Seni pertunjukan rakyat telah lama dikenal sebagai media lokal yang dimaanfaatkan oleh pemerintah pada zaman dahulu dalam menyampaikan pesan pembangunan. Tema yang biasanya berkembang dalam seni pertunjukan rakyat menyangkut ekspresi hidup, keteledanan, simbolsimbol, ritual, cita-cita budaya, dan nilainilai baik buruk. Disini seni pertunjukan rakyat berfungsi menuntun masyarakat untuk memahami batas baik dan buruk yang mesti dilakukan dan cara melakukannya. Kegunaan seni pertunjukan rakyat diutamakan untuk kepentingan hiburan, komunikasi sosial, 
dan aktivitas religius.

Pelestarian budaya menarik untuk diteliti lebih lanjut melalui perspektif pemaknaan tradisi dan budaya. Pencampuran tradisi dan budaya direfleksikan Heritere la Culture Theory sebagai kebudayaan harus diwariskan dari generasi ke generasi, dan harus sama tanpa ada perubahan ritual. Dialog Agama dan Budaya diperlukan untuk membangun hubungan harmonis atas pencampuran ritualistik tersebut. Heriter la Culture Theory, sebagaimana disampaikan Syahputra (2015 : 21) tentang konsep pewarisan budaya, bahwa komunitas kultural masa kini mewarisi kebudayaan nenek moyang secara turun temurun. Dan terus melestarikan sebagai kearifan bangsa. Perilaku pewarisan ini lebih sering terjadi pada budaya yang bersifat ritual, terutama dalam konteks keagamaan, sebut saja Tahlil dalam sebagian pemeluk Agama Islam, Mithoni dalam adat Jawa, Nyadran, dan lain-lain.

Lebih lanjut Syahputra (2015 : 22) menyampaikan bahwa pewarisan ini, akan terus berulang hingga generasi mendatang. Pelestarian ritual kultural, dalam teori ini didominasi oleh keyakinan, dan kepasrahan pengikut atas kontrol ajaran budaya. Artinya, apa yang sudah diyakini sebagai kebenaran, maka harus secara kolektif diyakini. Dalam Islam disebut sebagai Iman. Dalam kajian budaya, teori ini kental nuansa budaya tradisional, menjunjung tinggi kearifan bangsa (folk culture). Dalam masyarakat tradisional, folk culture ini bisa berupa tindakan, ekspresi, hingga interaksi yang tidak dirumitkan oleh mediasi medium. Dominasi folk culture ada pada tradisi, kebiasaan, masyarakatnya relatif terisolasi oleh keyakinan-keyakinan kultural, dan anti urbanisasi.
Wayang Golek merupakan salah satu kesenian tradisional yang berasal dari Provinsi Jawa Barat. Seperti dikutip dari www.pdwi.org, Wayang Golek adalah salah satu bentuk seni pertunjukan yang tumbuh dan berkembang di daerah Jawa Barat. Daerah penyebarannya terbentang luas dari Cirebon di sebelah timur sampai wilayah Banten di sebelah barat, bahkan di daerah Jawa Tengah yang berbatasan dengan Jawa Barat sering pula dipertunjukkan pergelaran Wayang Golek. Masyarakat di Jawa Barat mulai mengenal wayang pada tahun 1455 Saka atau 1533 Masehi dalam Prasasti Batutulis. Pendapat lain mengatakan penyebaran wayang di Jawa Barat dimulai pada masa pemerintahan Raden Patah dari Kerajaan Demak, kemudian disebarluaskan para Wali Songo. Termasuk Sunan Gunung Jati yang pada tahun 1568 memegang kendali pemerintahan di Kasultanan Cirebon. Beliau memanfaatkan pergelaran wayang kulit sebagai media dakwah untuk penyebaran agama Islam. Baru sekitar tahun 1584 Masehi salah satu Sunan dari Dewan Wali Songo yang menciptakan Wayang Golek, tidak lain adalah Sunan Kudus yang menciptakan Wayang Golek Pertama. Dalam perjalanan sejarahnya, pergelaran wayang golek mula-mula dilaksanakan oleh kaum bangsawan. Terutama peran penguasa terutama para bupati di Jawa Barat, mempunyai pengaruh besar terhadap berkembangnya wayang golek tersebut. Pada awalnya pertunjukan wayang golek diselenggarakan oleh para priyayi (kaum bangsawan Sunda) dilingkungan Istana atau Kabupaten untuk kepentingan pribadi maupun untuk keperluan umum. (http://www.pdwi.org).

Kelahiran wayang golek berasal dari ide Dalem Bupati Bandung (Karang Anyar) 
yang menugaskan Ki Darman, juru wayang kulit asal Tegal yang tinggal di Cibiru, untuk membuat bentuk golek purwa. Awalnya wayang kayu ini masih dipengaruhi bentuk wayang kulit, yaitu gepeng atau dwimatra. Pada perkembangan selanjutnya, tercipta bentuk golek yang semakin membulat atau trimatra seperti yang biasa kita lihat sekarang. Kemudian, pembuatan golek pun menyebar ke seluruh wilayah Jawa Barat seperti Garut, Ciamis, Ciparay, Bogor, Karawang, dan Majalengka (Rosyadi, $2009: 141)$

Definisi Wayang menurut Kamus Besar Bahasa Indonesia (2008) merupakan boneka tiruan orang yang terbuat dari pahatan kulit atau kayu dan sebagainya yang dapat dimanfaatkan untuk memerankan tokoh dalam pertunjukan drama tradisional (Bali, Jawa, dan Sunda), biasanya dimainkan oleh seseorang yang disebut dalang. Dalam kehidupan masyarakat di Jawa Barat kesenian wayang difungsikan kedalam dua bentuk pergelaran, yaitu : untuk hiburan dan untuk ruatan (upacara ritual). Bagi masyarakat Jawa Barat kecuali Cirebon dan Indramayu, wayang golek disebut dengan sebutan wayang golek saja sedangkan masyarakat Cirebon dan Indramayu menyebut wayang golek dengan wayang golek purwa. Wayang golek adalah seni pertunjukan wayang yang terbuat dari bahan kayu yang menyerupai bentuk manusia. Boneka yang terbuat dari kayu ini yang disebut dengan golek. Oleh karena itu wayangnyapun disebut dengan wayang golek. Pertunjukan wayang golek melibatkan seorang dalang yang dijadikan sebagai bertindak sebagai pencerita (narator) maupun sebagai pemain wayang.

Wayang golek merupakan alat komunikasi yang lengkap, yaitu alat komunikasi audio-visual yang telah lama akrab dengan audiensnya dengan aneka pesan, falsafah, dan ajaran moral yang dikemas dalam bentuk cerita yang disampaikan oleh dalang.

\section{METODE PENELITIAN}

Metode yang digunakan dalam penelitian ini adalah metode kualitatif dengan pendekatan fenomenologi. Dalam penelitian ini, peneliti bermaksud untuk memahami, menggambarkan dan mendiskripsikan secara mendalam tentang suatu fenomena yang menjadi fokus permasalahan, yaitu memahami strategi komunikasi pembangunan melalui kesenian rakyat wayang golek dalam penggunaannya sebagai media komunikasi pembangunan.

Objek pada penelitian ini adalah strategi pewarisan budaya dan komunikasi pembangunan melalui kesenian rakyat wayang golek yang digunakan sebagai media komunikasi penyebaran informasi program pembangunan di beberapa wilayah provinsi Jawa Barat. Melalui data yang akan didapatkan pada wawancara dengan informan kunci dan pendukung, peneliti mengklasifikasikan data tersebut difokuskan pada pewarisan budaya dan pemanfaatan wayang golek sebagai media komunikasi pembangunan yang tercermin dalam strategi komunikasi pembangunan melalui wayang golek oleh Dinas Komunikasi dan Informatika Jawa Barat.

Adapun teknik pengumpulan data yang gunakan pada penelitian ini adalah observasi kultural dengan mengumpulkan data ikut observasi partisipatif dalam beberapa kegiatan penyebaran informasi tentang internet sehat dan aman melalui media 
pertunjukan rakyat wayang golek ke beberapa tempat. Selain itu peneliti juga melaksanakan wawancara mendalam dengan beberapa pihak yang memiliki kapabilitas dan perhatian terhadap seni budaya dan wayang golek.

\section{HASIL DAN ANALISIS}

Wayang Golek merupakan sebagai kesenian tradisional yang berasal dari wilayah Provinsi Jawa Barat adalah karya seni adiluhung yang merupakan perpaduan berbagai macam karya seni, ada seni ukir, seni tutur, seni peran, dan seni pertunjukan secara keseluruhan. Wayang Golek daerah penyebarannya terbentang luas dari Cirebon di sebelah timur sampai wilayah Banten di sebelah barat, bahkan di daerah Jawa Tengah yang berbatasan dengan Jawa Barat sering pula dipertunjukkan pergelaran Wayang Golek.

Menurut dalang Tantan Sugandi (Wawancara dengan tim peneliti : 2017), sejarah perkembangan wayang golek memang tidak dapat dilepaskan dari keberadaan wayang kulit di Jawa Tengah dan Jawa Timur. Jika wayang kulit di Jawa dipertunjukkan pada malam hari, dengan berbagai alasan dan pertimbangan seperti keamanan dan matapencaharian penduduk di wilayah Jawa Barat (Sunda) pada waktu itu, maka diciptakanlah wayang 3 dimensi (3D) yang dapat dilihat pada siang hari. Di tatar Parahyangan sendiri, perkembangan wayang golek klasik penyebarannya dimulai dari daerah Cibiru, dengan masih menggunakan bentuk wayang yang sederhana hanya sekadar lambang-lambang, bentuk yang menyerupai manusia dan diwarnai seadanya.

Saat ini, pertunjukan wayang golek mengalami perkembangan yang cukup signifikan dari sisi penciptaan tokoh wayang maupun pengemasan dan intensitas pertunjukan wayang golek di wilayah Jawa Barat. Sebagaimana disampaikan salah satu dalang wayang golek, Tantan Sugandi :

“...sekarang ini perkembangan wayang golek sedang bagus, karena ide kreatif muncul, kemudian dengan tetap masih mempertahankan nilai tradisinya. Tetapi kalau masalah pertunjukan, meskipun intensitasnya mengalami perkembangan dibandingkan tahuntahun sebelumnya, namun kurang ekspos dari masyarakat atau mungkin dari media (media massa). (Hasil wawancara tim peneliti : 2017)"

Pertunjukan wayang golek yang kurang terekspos oleh media, menurut Tantan juga dipengaruhi oleh porses regenerasi dalang wayang golek yang berlangsung lambat. Tidak seperti ketika jaman dalang Abah Asep Sunandar Sunarya dan Dede Amung Sutarya. Dimana setiap ada pertunjukan wayang golek, masyarakat selalu mendapatkan informasi tentang pertunjukan yang sedang berlangsung di daerah-daerah tertentu karena dengan ketenaran dalang tersebut, informasi mengenai pertunjukan wayang golek mudah menyebar ke tengah masyarakat, baik melalui media ataupun komunikasi secara langsung yang menyebar dari mulut ke mulut.

Di Jawa Barat sendiri, saat ini telah berkembang sebuah komunitas pecinta wayang golek Pamiarta Wayang Golek dengan cakupan wilayah di Bandung, Cimahi, Bogor, Karawang sampai ke Bekasi. Komunitas ini dibentuk sebagai wadah untuk mempererat silaturahmi pecinta wayang golek di wilayah Jawa Barat, sekaligus sebagai sarana untuk melestarikan seni tradisi wayang golek 
dan seni tradisi lainnya di wilayah Jawa Barat. Salah satu tokoh Pamiarta Wayang Golek, Bahrama Warugawan, menyampaikan :

"Komunitas Pamiarta Wayang Golek itu sendiri merupakan sebuah wadah untuk mempererat tali silaturahmi, kalau dalam bahasa Sunda manjangkeun tali mimitran babayaran", yang kebetulan dalam komunitas tersebut satu hobi, satu hati, satu tekad, satu tujuan untuk melestarikan seni tradisi wayang golek lewat sebuah komunitas pecinta seni wayang golek. (hasil wawancara tim peneliti : 2017)"

Jadi melalui komunitas ini para anggota komunitas yang terdiri dari berbagai latar belakang pendidikan dan pekerjaan, mulai dari pelajar sampai dosen saling berbagi informasi tentang pertunjukan wayang golek yang akan berlangsung. Dengan kegiatan nonton bareng wayang golek, komunitas ini berharap dapat menyebarkan virus kecintaan mereka terhadap kesenian rakyat wayang golek di kalangan masyarakat, terutama generasi muda.

\section{Pewarisan Budaya Wayang Golek di Jawa Barat}

Keberadaan wayang golek di Jawa Barat saat ini mengalami perkembangan yang cukup menggembirakan dalam hal jumlah pertunjukan dan jumlah dalang muda yang ada. Menurut data dari Pamiarta Wayang Golek Jawa Barat, di Bandung, tercatat tidak kurang dari 45 orang dalang yang aktif. Namun tidak semua dalang tersebut dapat melaksanakan pentas atau pertunjukan karena terbatasnya permintaan. Di Jawa Barat juga telah dibentuk organisasi PEPADI yang mewadahi para dalang.

Untuk mewariskan wayang golek juga diperlukan inovasi-inovasi dan ide-ide kreatif agar wayang golek semakin disukai dan dicintai oleh anak muda. Globalisasi informasi dan media saat ini harus dapat dimanfaatkan sebagai sarana dan media untuk mempertahankan kesenian daerah warisan bangsa. Wayang golek mengalami perkembangan nilai dan inovasi tanpa meninggalkan pakempakem utama (tradisional) yang telah ada sebelumnya. Penciptaan tokoh Cepot dalam seni pewayangan di Jawa Barat adalah salah satu inovasi yang cukup berhasil untuk menjaga agar wayang golek dapat diwariskan kepada generasi penerus tanpa meninggalkan cerita utama.

Selain itu proses revitalisasi juga dilakukan dalam rangka pewarisan wayang golek ini. Sebagaimana disampaikan M. Duleh (2017), pembuat wayang golek di Cibiru, Kabupaten Bandung, bahwa bentuk dan karakter tokoh-tokoh wayang golek mengalami beberapa perubahan dari asal mulanya. Mulai dari model pakaian yang dikenakan pada tokoh wayang sampai warna muka wayang telah mengalami perubahan sesuai dengan perkembangan jaman. Duleh menyampaikan :

"Kalau dulu aslinya wayang klasik, pakaiannya pakaian biasa. Tapi sekarang kan sudah bukan jamannya, nah sekarang pakaiannya sudah bagus. Dari pengecatannya juga udah modern. Seperti karakter Gatotkaca misalnya sekarang ini dikasih warna muka hijau, kekuningkuningan sedikit, jadi orangnya karakternya jujur, patuh kepada negara dan bangsa" (Hasil wawancara tim peneliti : 2017).

Dalam pewarisan kesenian wayang golek ini, para dalang dituntut mampu membawakan cerita sesuai dengan pakem tetapi juga dapat mengikuti 
perkembangan jaman. Hal ini dilakukan agar generasi muda memiliki ketertarikan terhadap budaya luhur warisan nenek moyang mereka. Menurut penuturan Bahrama, dalang harus pintar, yaitu pintar mengolah cerita dari berbagai kerajaan yang ada dalam cerita pewayangan, juga harus pintar memainkan karakter yang ada dalam tokoh-tokoh pewayangan. Wayang golek juga harus direinterpretasikan sesuai dengan keadaan sekarang, tanpa mengubah pakem tatakon pewayangan dan pedalangan.

Sekarang ini, telah mulai muncul dalangdalang muda di tatar Sunda. Di tengah pengaruh budaya modern yang sangat kuat masih terdapat anak-anak muda yang mau belajar seni budaya pedalangan, khususnya wayang golek. Dalam penelitian ini informan yang diwawancarai salah satunya adalah Bima dan Warsim yang merupakan siswa kelas 11 SMKN Bandung yang mengambil kelas Sekar Pedalangan, yang mempelajari teknik vokal pedalangan, kakawen, sabet dan suara wayang. Kedua remaja ini juga sudah terampil memainkan wayang dalam sebuah pertunjukan wayang golek. Bima dan Warsim memilih menggeluti dunia pewayangan dengan alasan karena mencintai budaya Indonesia, khususnya seni wayang. Mereka berkeinginan membangkitkan lagi seni wayang golek di kalangan generasi muda, untuk mempertahankan budaya bangsa menghadapi invasi budaya dari luar yang tidak sesuai dengan kepribadian dan identitas bangsa Indonesia. Sebagaimana mereka sampaikan :

"Jadi, kita selaku generasi muda harus mencintai budaya sendiri, khususnya seni, yaitu seni wayang. Terkenalnya Negara Indonesia bukan karena bidang militernya, bukan dengan bidang politiknya, tapi oleh budayanya (Hasil wawancara tim peneliti : 2017)."

Sementara itu, menurut Bahrama, diperlukan dukungan dari pemerintah, baik pemerintah pusat maupun pemerintah daerah dalam rangka pewarisan budaya-budaya lokal di Indonesia, termasuk seni wayang golek. Meskipun telah ada peran pemerintah daerah dalam pewarisan dan pengembangan seni wayang golek, namun dirasakan lebih banyak peran seniman seni Sunda.

\section{Wayang Golek sebagai Media Komunikasi Sosial}

Sebagai seni pertunjukan tradisional, wayang golek merupakan media penyampai pesan (media komunikasii) yang efektif, karena dalam pertunjukannya wayang golek menjadi sebuah hiburan yang dapat menyisipkan pesan-pesan tertentu. Dalang wayang golek tidak hanya berperan sebagai pelakon yang memainkan tokoh-tokoh wayang saja, tetapi sekaligus sebagai penyampai pesan-pesan tentang kehidupan sehari-hari, agama, dan pesan-pesan moral lainnya kepada audiens. Menurut Bahrama Warugawan (Sekretaris Komunitas Pamiarta Wayang Golek Jawa Barat), bahasa yang digunakan dalam penyampaian pesan di dalam pertunjukan wayang golek terkadang bukanlah bahasa sehari-hari, tetapi menggunakan bahasa pedalangan yang disebut silip, sindir, suakadar, dan sasmita.

Dalam menyampaikan pesan-pesan yang mencakup berbagai aspek kehidupan, dalang wayang golek menggunakan bahasa sastra pedalangan. Sehingga ketrampilan dalang untuk mengolah kata-kata dan cerita menjadi sangat 
penting agar pesan yang akan disampaikan dapat diterima audiens. Bahrama yang sudah cukup lama malang melintang dalam dunia pewayangan menyampaikan pendapat sebagi berikut:

"Jadi pesan apapun, termasuk di dalamnya pesan mengenai kenakalan remaja atau tentang terorisme juga bisa, segala macam yang mencakup aspek-aspek kehidupan dapat tersampaikan melalui sebuah pagelaran wayang. Kalau dalangnya pinter-pinter mengolah bahasa, pinter cara penyampaiannya, dapat dimengerti para penonton, pesan apapun bisa dipahami (kena) (Hasil wawancara tim peneliti : 2017)"

Selain dengan pengolahan cerita dan kata-kata, pesan dalam dunia pewayangan juga dikemas dalam sifatsifat tokoh pewayangan. Bahrama memberikan contoh bagaimana pesan tentang nasionalisme, terutama tentang bagaimana sikap membela negara yang patut dicontoh generasi muda terdapat dalam sifat tokoh Gatotkaca. Tokoh ini adalah sosok pembela bangsa sejati yang hanya melindung (bebenteng) Negara, dan mengabdikan hidupnya demi membela Negara. Dalam cerita wayang Bharatayuda lakon Jaya Perbangsa, diceritakan bagaimana pengorbanan Gatotkaca yang rela hancur dan gugur di medan perang akibat senjata Adipati Karna demi kemenangan negaranya. Gatotkaca yang seorang ksatria sakti mandraguna tidak menyombongkan diri dan tetap mau berjuang demi negaranya. Dari tokoh ini ada pesan yang dapat disampaikan kepada generasi muda agar menjadi orang yang tidak sombong dan tinggi hati, juga agar menjadi orang yang jujur dan patuh serta hormat kepada yang lebih tua.

Wayang golek menurut Tantan Sugandi adalah sarana atau media komunikasi yang masih sangat efektif di era globalisasi sekarang ini. Hal ini karena menjadi tugas seorang dalang untuk tidak hanya menjadi penghibur bagi penontonnya, tetapi juga dituntut untuk mampu menyampaikan pesan-pesan yang baik. Tantan mengatakan :

"Wayang itu sebagai media saja yang bisa dipakai, jadi tergantung dalangnya, apapah mau dijadikan sebagai media penyampai pesan tentang kebaikan atau keburukan. Karena wayang itu masih efektif sebagai sarana komunikasi, antara program" (Hasil wawancara tim peneliti: 2017).

Lebih lanjut dalang Tantan (2017) menyampaikan bahwa tugas pokok dalang itu ada 3 (tiga) yang disebut dengan Trikar Dharma. Tugas pertama adalah sebagai juru penerang, yang memberikan penerangan kepada masyarakat atau menyampaikan pesanpesan titipan dari pemerintah, misalnya tentang pemili, pertanian, dan keluarga berencana. Yang kedua, dalang bertugas menjadi juru pendidik. Sehingga dalang harus memiliki wawasan yang luas, harus berpendidikan dan harus mampu mendidik masyarakat. Tugas ketiga dalang adalah sebagai penghibur (entertainer) yang memberikan hiburan kepada penontonnya. Hal ini lah yang menjadikan wayang golek sebagai media penyebaran agama dan dakwah sampai sekarang ini di wilayah Jawa Barat. Jadi pesan yang disampaikan ada yang secara langsung dilisankan kepada masyarakat, tetapi juga seringkali dibungkus dalam satu kemasan cerita. Sindiran-sindiran atau satire khas Sunda seringkali disampaikan dalang untuk melakukan kritik kepada para pejabat yang ada di daerah maupun di tingkat pusat. Sebagai hasil karya seni asli Indonesia, wayang golek masih efektif untuk digunakan 
sebagai media komunikasi bagai generasi muda.

\section{PEMBAHASAN}

Dalam pewarisan seni dan budaya, terdapat beberapa macam cara dan metode. Sebagaimana disampaikan oleh Guru Besar Seni Rupa Institut Seni Indonesia Surakarta, Prof. Dharsono (Wawancara dengan tim peneliti, 2017), bahwa pewarisan budaya dapat berupa :

1. Preservasi : dimana pewaris budaya berupaya untuk melindungi dan merawat hasil karya seni budaya yang sudah ada.

2. Konservasi : generasi penerus seni budaya mengembangkan nilai dan inovasi yang didasari dari warisan seni budaya yang telah ada sebelumnya.

3. Revitalisasi : membuat tiruan dari artefak seni budaya warisan leluhur. Sebagaiman wayang golek dibuat tiruannya, itu sah, karena penciptanya anonim.

4. Reinterpretasi : pewaris budaya mencari ide penciptaan yang sama dengan ide penggarapan dari warisan seni budaya yang telah ada. Misalnya kisah-kisah dalam dunia pewayangan yang diinterpretasikan ulang.

Dalam perkembangan wayang golek di Jawa Barat, hampir semua stakeholder yang terlibat menggunakan sistem konservasi, dimana wayang golek mengalami perkembangan nilai dan inovasi tanpa meninggalkan pakempakem utama yang telah ada sebelumnya. Penciptaan tokoh Cepot dalam seni pewayangan di Jawa Barat adalah salah satu inovasi yang cukup berhasil untuk menjaga agar wayang golek dapat diwariskan kepada generasi penerus tanpa meninggalkan cerita utama. Selain itu proses revitalisasi juga dilakukan dalam rangka pewarisan wayang golek ini. Sebagaimana disampaikan M. Duleh, pembuat wayang golek di Cibiru, Kabupaten Bandung, bahwa bentuk dan karakter tokoh-tokoh wayang golek mengalami beberapa perubahan dari asal mulanya. Mulai dari model pakaian yang dikenakan pada tokoh wayang sampai warna muka wayang telah mengalami perubahan sesuai dengan perkembangan jaman.

Proses reinterpretasi juga terjadi dalam pewarisan kesenian wayang golek ini, dimana para dalang dituntut mampu membawakan cerita sesuai dengan pakem tetapi juga dapat mengikuti perkembangan jaman. Hal ini dilakukan agar generasi muda memiliki ketertarikan terhadap budaya luhur warisan nenek moyang mereka. Menurut penuturan Bahrama, dalang harus pintar, yaitu pintar mengolah cerita dari berbagai kerajaan yang ada dalam cerita pewayangan, juga harus pintar memainkan karakter yang ada dalam tokoh-tokoh pewayangan. Wayang golek juga harus direinterpretasikan sesuai dengan keadaan sekarang, tanpa mengubah pakem tatakon pewayangan dan pedalangan.

Sedangkan pencampuran tradisi dan budaya direfleksikan oleh Heritere la Culture Theory sebagai kebudayaan yang harus diwariskan dari generasi ke generasi, dan harus sama tanpa ada perubahan ritual. Heriter la Culture, teori ini menjelaskan tentang konsep pewarisan budaya, komunitas kultural masa kini mewarisi kebudayaan nenek moyang secara turun temurun. Dan terus melestarikan sebagai kearifan bangsa. Perilaku pewarisan ini lebih sering terjadi pada budaya yang bersifat ritual, 
terutama dalam konteks keagamaan, dalam hal ini wayang golek Sunda. Di tengah perkembangan teknologi informasi dan komunikasi saat ini, seni budaya adalah salah satu cerminan identitas bangsa. Sehingga pelestarian seni budaya, termasuk wayang golek, sudah seharusnya dilakukan secara terus menerus kepada generasi muda agar kesenian tradisional warisan bangsa ini tidak hilang. Dalam melakukan pewarisan, meskipun dibutuhkan inovasi, tetapi jangan sampai merusak pakem dari seni pewayangan itu sendiri.

Sebagai produk budaya, para pelaku budaya di Jawa Barat melakukan upaya pewarisan budaya (transmission of culture) terhadap Wayang Golek sebagai ritual performing art maupun sebagai ritual magis (pendekatan sosiologis), dari satu generasi ke generasi manusia atau masyarakat berikutnya melalui proses pelestarian budaya lama (heritere la culture). Sesuai dengan hakikat dan budaya sebagai pemilik bersama masyarakat maka unsur-unsur budaya wayang itu memasyarakat dalam individu-individu warga masyarakat dengan jalan diwariskan atau dibudayakan melalui proses belajar budaya.

Proses pewarisan budaya wayang dilakukan melalui proses enkulturasi, wayang dianggap sebagai satuan tradisi yang harus di jaga, bermanfaat bukan sebatas sebagai ritual melainkan sebagai identitas. Wayang sebagai tradisi merupakan satu-satunya penanda keberadaan budaya di satu wilayah, untuk itu kesadaran masyarakat Jawa Barat terhadap pelestarian wayang sangat tinggi, karena anggapan mereka wayang bukan persoalan performing art. Tetapi identitas kebersamaan (societas cultural). Heritere la culture dilakukan dengan penguatan sosialisasi (belajar atau mempelajari budaya). Pewarisan budaya wayang umumnya dilaksanakan melalui saluran lingkungan keluarga, masyarakat, sekolah, lembaga pemerintahan, perkumpulan, institusi resmi, dan media massa.

Selain itu Wayang Golek juga dianggap sebagai adat, yang dimaksudkan bahwa wayang tetap lestari karena digunakan sebagai alat adat istiadat, yakni memaknai wayang sebagai ritual. Semisal, pertunjukan saat pernikahan, atau hajatan besar masyarakat sunda. Melalui proses pewarisan budaya maka akan terbentuk manusia-manusia yang memiliki kepribadian selaras dengan lingkungan alam, sosial dan budayanya disamping kepribadian yang tidak selaras (menyimpang) dengan lingkungan alam, sosial dan budayanya. Wayang, ketika ditransformasikan dalam adat maka akan menyatu dengan kesharian masyarakat.

Mencermati kebudayaan Jawa Barat yang beragam, wayang adalah satu representasi kebudayaan bangsa Sunda. Sehingga keberlangsungan wayang dapat disetarakan dengan keberlangsungan kebudayaan, yang terbangun dalam harmoni, sebagaimana yang kita saksikan di Indonesia, di mana praktik harmony in diversity, begitu terasa dan kental dalam gelutan hidup keseharian masyarakat dan bangsa ini. Halnya dengan pewayangan, keharmonian budaya kental, karena wayang tidak saja penanda Sunda, melainkan Indonesia dalam artian yang lebih luas.

\section{SIMPULAN}

Masyarakat Sunda tersusun dari lapisan yang majemuk, terdiri dari kekayaan 
ragam yang eksotik, kebiasaan, bahkan agama juga sistem nilai sekalipun. Dengan memahami konsep yang terbangun dari sifat keberagaman, maka menjadi mudah interaksi yang terjalin antar kelompok yang berbeda. Ini penting, sebagai bagian dari mengisi kekosongan makna. Pemahaman tentang keberagaman masyarakat terkait perlunya pewarisan budaya melalui sudut pandang Heritere La Culture, mengikuti beberapa hal. Pertama, masyarakat kultural memiliki struktur beragam, karena masing-masing entitas membawa keragaman sendiri. Sehingga, perlu melakukan adaptasi antar entitas yang saling bertemu. Ketidakteraturan ini karena sifat keanekaragaman latar belakang itu tadi. Kedua, kepentingan bersama melebihi apapun, untuk itu semangat yang terbangun dalam keberagaman masyarakat adalah semangat kebersamaan yangm emprioritaskan kebaikan bersama di atas kebaikan individu.

Ketiga, masyarakat multi generasi mudah dihinggapi konflik modernitas, gaya hidup, dan kebiasaan. Oleh karena diperlukan kearifan dalam berinteraksi, memahami perbedaan sebagi bagian dari karakter kesatuan kebudayaan. Menjadi masyarakat komunitas sangat penting, karena individu-individu tidak akan mementingkan tafsir personal untuk melihat satu persoalan. Ketersalingan mengalah dan mencari celah komunikasi merupakan keniscayaan.

Keempat, struktur sosial bersifat nonkomplementer. Ini dimaksudkan ketidaklengkapan susunan kultural dalam masyarakat, atau justru karena terlalu banyaknya lembaga-lembaga kultur dari masyarakat. Sehingga ketika kesemuanya digabung satu sama lain saling bentrok atau tidak serasi. Kelima, proses integrasi lambat. Lambatnya integrasi masyarakat kultural karena penjelasan poin keempat di atas. Ketidakserasian pemikiran dan susunan kelembagaan budaya. Sehingga proses integrasi harus dipaksa ditengah-tengah masyarakat kultural. Wayang dianggap sebagai hal sakral, sama seperti memberikan doa-doa melalui pohonpohon besar, kuburan keramat, batu besar dan materi lainnya. Tetapi doa tetap menggunakan konsep keislaman. Hal demikian secara jujur tidak baik, tetapi itu yang dapat dijadikan alternatif. Keenam, dominasi ekonomi, politik dan budaya. Masyarakat kultural yang mendominasi akan cenderung untuk melakukan hegemoni.

\section{REFERENSI}

Berger, Peter L. dan Thomas Luckman. The Social of Construction Reality, 1996

Danasasmita, Saleh dan Anis Djatisunda. Kehidupan Masyarakat Kanekes. Bandung: Sundanologi, 1986.

Danial, Ahmad. Media dan Iklan Politik. Yogyakarta: Jalasutra, 2001.

Dananjaya, James. Folklore Indonesia ; Ilmu Gosip, Dongeng dan lainlain. Pustaka Grafiti Pers. 1986.

Dilla, Sumadi. Komunikasi Pembangunan : Pendekatan Terpadu. Bandung : Simbiosa Rekatama. 2010.

Ellul, Jacques. "Masyarakat Teknologi", dalam Mangunwijaya, Y. B. 1993. Teknologi dan Dampak Kebudayaannya, Volume I. Jakarta: Yayasan Obor Indonesia.

Indrayanti, Sukma. Media dan Masyarakat Modern. Yogyakarta: Kencana Mega, 2001

McQuail, Dennis. Teori Komunikasi Massa McQuail. Jakarta: Salemba Humanika, 2011 
Mumfangati, Titi. Kearifan Lokal di Lingkungan Masyarakat Samin kabupaten Blora Jawa Tengah. Yogyakarta: Jarahnitra, 2004

Poesponegoro, Marwati Djoened dan Nugroho Notosusanto. Sejarah Nasional Indonesia III: Jaman Pertumbuhan dan Perkembangan Kerajaan Islam di Indonesia. Jakarta: Balai Pustaka, 2008

Purwasito, Andrik. Komunikasi Multikultural. Surakarta. Universitas Muhammadiyah Surakarta, 2003.

Rosyadi, Wayang Golek Dari Seni Pertunjukan Ke Seni Kriya (Studi tentang Perkembangan Fungsi Wayang Golek di Kota Bogor), Jurnal Patanjala Vol. 1, No. 2, Juni 2009: 135 - 148.

Soekmono, R. Pengantar Sejarah Kebudayaan Indonesia. Yogyakarta: Kanisius, 2008

Strinati, Dominic. Popular Culture: Pengantar Menuju Teori Budaya Populer. Yogyakarta: Ar-Ruzz Media. 2009 Syahputra. Dedi Kurnia. Interaksi Lintas Budaya. Bandung : Yayasan Multikultural Indonesia, 2015.

Widyosiswoyo, Supartono. Sejarah Kebudayaan Indonesia. Jakarta: Universitas Trisakti, 2006. 